Article

\title{
Educating Digital Citizens: An Opportunity to Critical and Activist Perspective of Sustainable Development Goals
}

\author{
Antonia Lozano-Díaz ${ }^{1}$ (D) and Juan S. Fernández-Prados ${ }^{2, *(D)}$ \\ 1 Department of Education, University of Almería, 04120 Almería, Spain; ald805@ual.es \\ 2 Department of Sociology, University of Almería, CEMyRI, 04120 Almería, Spain \\ * Correspondence: jsprados@ual.es; Tel.: +34-950-015-221
}

Received: 6 August 2020; Accepted: 1 September 2020; Published: 4 September 2020

check for updates

\begin{abstract}
The 2030 Agenda sets out seventeen Sustainable Development Goals (SDGs). The educational goal is to promote the education of citizens on sustainable development, among other things. Educating today's digital citizens on sustainability means training them for justice and social activism, commitment and political engagement. However, research into the subject shows a lack of consistency in the education of university students. This paper presents a study of students of Education, on education on sustainability through the practice of active and critical digital citizenship. A quasi-experimental method was used to learn about the behaviors of digital citizens, and intervention was carried out by means of an SDG-focused workshop and observation of the final level of commitment. The results show a positive level of commitment and digital activism around content related to sustainable development, which can be addressed from the university syllabus in a cross-curricular way.
\end{abstract}

Keywords: sustainable development goals; 2030 agenda; digital citizenship; digital activism; syllabus-related sustainability; social justice

\section{Introduction}

Several guidelines have been adopted by the United Nations (UN) and its agencies on how to approach the development of human activity in a sustainable way, ultimately culminating in the approval of the 2030 Agenda for Sustainable Development [1]. This document lays out the seventeen Sustainable Development Goals and calls on all countries to work together responsibly in achieving them [2]. In the goal dedicated to education, Number 4, the UN dedicates a specific part, Section 4.7, to the requirement for learners to acquire knowledge and skills needed to promote sustainable development. In this way, it challenges the educational community at all levels and transfers to them the responsibility to educate learners on and for the achievement of the Sustainable Development Goals (SDGs). Thereby, UNESCO understands the Education for Sustainable Development (ESD) empowers learners to take informed decisions and responsible actions for environmental integrity, economic viability and a just society for present and future generations [3]. In the case of Spain, the guidelines adopted by university academics are included in documents that lay the foundations on sustainability training for professional qualifications and the all-round education of graduates [4].

This paper summarizes a research project on education in the global and social citizenship skills of university students studying Education. To do so, it has used strategies of digital activism or cyber-activism based around sustainability-based content (the SDGs). In the theoretical framework, an initial analysis is made of what education in sustainability means, which educational strategies for sustainable development are being developed in universities, and which needs, and problems 
have been detected. Secondly, it establishes the role of digital citizenship and activism can play in the training of future educators to teaching and engaging on SDGs.

\subsection{University Education in Sustainability}

The educational idiosyncrasy of a university makes it a tier-one agent in educating citizens on the values and principles of sustainability [5]. Educating on and for the SDGs means educating for social justice and sustainable development, for social activism and for political commitment and engagement [2,6]. It entails educating citizens who question justice and equal opportunities in the sense of human rights [7]. Educating future teachers based on activism and critical pedagogy is essential, as it is one of the measures which most influences their students' results [8]. Initial teacher training must therefore address sustainability skills [9,10], through critical, ethical [11,12], conscious [11,13], interdisciplinary and social interaction practices [8,12-15].

After a decade of Education for Sustainable Development (2005-2014), Wals [16] concluded that Higher Education Institutions in the world are beginning to make more systemic changes towards sustainability by re-orienting their education, research, operations and community outreach activities all simultaneously. A more recent survey of almost 400 European universities finds considerable progress in the incorporation of sustainable development (SD) into higher education institutions' curricula, based on 'connecting sustainable development pedagogical approaches to competences' framework [17]. In a study on sixteen university degrees in Spain, Albareda-Tiana, Vidal-Raméntol and Fernández-Morilla [18] conclude that significant improvements are required in the methodology and content of degrees. The implementation of education in sustainability in the university syllabus in Spain is slow and insufficient [19], lacks teacher involvement [19,20] and even lacks an appropriate approach to the subject [21]. University students are not considered to have been trained in sustainability $[19,22]$. In short, there is a notable lack of consistency with the formal sustainability requirements established by the Association of Vice-Chancellors of Spanish Universities [18].

The 2019 report on the Sustainable Development Goals [23] states that, despite the progress made, we are moving too slowly in areas which call for urgent collective attention, such as the environment, the end of human suffering, and the creation of opportunities for everyone. A broader, faster and more ambitious response is needed from areas that have shown their effectiveness, such as science and innovation, with a greater focus on digital transformation.

\subsection{Cyberactivism as an Expression of a Critical and Participatory Digital Citizenship}

The term digital citizenship is used as a synonymous of cybercitizeship/ecitizenship. It is often taken as "digital literacy" (media and digital literacy) [24,25], but it involves much more than this. The ideal digital citizen is part of an Online community ruled by the principles of respect, education and protection [26,27]. Furthermore, Gleason and Guillern [28], state that digital citizens are self-taught and create their own identity through active participation on social networks. Emejulu and McGregor [29], highlight the need of a radical digital citizenship based on criticism and social justice. In short, a respectful, active and radical digital citizenship is an opportunity for a critical education as well as a democratic engagement [30,31].

The Council of Europe [32] incorporates the huge impact of the digital environment on life, economy and today's society, as well as on education and citizen engagement. It considers the digital world as an exceptional means for people to express themselves, engage in and create new forms of social participation. It defines digital citizenship as "the capacity to participate actively, continuously and responsibly in communities (local, national, global, online and offline) at all levels (political, economic, social, cultural and intercultural)". A contextual principle considered as "precondition" for digital citizenship is access to digital technology. Therefore, equality of access for all citizens, including access in schools, libraries and public institutions, and the balanced use of age-appropriate technology are important policy objectives. In the same document, Digital Citizenship Education is 
described as the empowerment of students through learning and active engagement in the digital society to exercise and defend their rights and obligations, as well as to promote and protect human rights.

Authors such as Schroeder [33] consider that academics have not fully addressed the potential that social network sites (SNS) and the digital environment have as a transformative, open, inclusive and reflective element of learning. Digital media should be understood as an environment full of opportunities for community engagement from the perspective of critical pedagogy, educating citizens in how to question social and structural inequalities through reflection and, above all, social and political engagement and involvement [34]. Blevins [35] asserted that for young people having the opportunity to engage in discussions, decisions and actions from different points of view they need to be committed and active members with their environment. Young people are not politically disaffected, as shown by various protest movements ("15M" and "Fridays For Future" are some examples), but instead use new forms of unconventional political engagement through social networks [36]. Amin [37] defines digital activism as "how citizens can use digital tools to affect social and political change", besides, it also gives a voice to groups usually marginalized in the media [38].

Digital activism is not without criticism: it is branded as activism for lazy people, clicktivism or slacktivism, with little impact on real actions [39], and even that it only complements the activity of those already committed [40]. However, various meta-analysis studies [41,42] show the correlation between digital activism and real-life actions. Despite the criticisms, cyberactivism forces us to consider its legitimacy as a form of social and political action [42-45], which underlines the need to develop good educational practices that facilitate engagement in political actions on the Internet [46,47]. In fact, young university students state that they have enough digital training, and yet they demand that they need more active and critical socio-political training on the Internet [48], with cyberactivism being an ideal way of doing so [48,49]. According to Amgott [48], digital activism should not be limited to slacktivism, but should be joined to other actions in the fight for social justice:

- Accessing different information and points of view

- Focusing on social and political issues

- Developing actions to foster social justice both globally and locally.

Considering the above, the objectives of this paper are to discover the digital activism behaviors and experiences of Education undergraduates and to learn about the digital activism behaviors of Education undergraduates when they have developed activities related to the Sustainable Development Goals.

\section{Materials and Methods}

The methodological design is quasi-experimental, pre-test/post-test with a single group, as it seeks to initially find out the level of digital citizenship of Education undergraduates. It later investigates a workshop on education for the SDGs where the students develop various related cyber interactions and, ultimately, it re-evaluates their digital citizenship to analyze the differences.

\subsection{Sample}

The selection of the sample was non-probabilistic and incidental, as the aim was to work exclusively with Education undergraduates. Students participation was entirely voluntary. Confidentiality of the information and data provided were guaranteed. As a result, the sample consisted of students from the University of Almería studying for degrees in Primary Education, Early Childhood Education and Social Education. In total, 302 students completed the entire process described below, which took place in the first semester of the 2019-20 academic year. The pre-test phase, the questionnaire on "digital citizenship" was sent out to 412 volunteer students and answered by 361, giving a response rate of $88 \%$. In the post-test phase, the same 361 participants were sent out the same questionnaire and was completed by 302 , giving a response rate of $84 \%$. In summary, our final sample was 302 students who participated in the entire process. 
The most outstanding sociodemographic characteristics of the sample were high levels of responses from female students and younger students (see Table 1). More than eighty percent of the participants were women $(82.8 \%)$ and almost half were only 17 or 18 years old $(47.7 \%)$ with a mean age of 20.35 (SD = 4.7), due to the characteristics of first-year degree courses in education. In addition, basic information was collected on the relationship with the Internet, number of hours connected per day and frequency of use of social networks to take in information. No student reported any Internet access problems; in reality, all students connect daily and 63\% connect for 3 hours or more a day.

Table 1. Sociodemographic and connection characteristics of the sample.

\begin{tabular}{ccc}
\hline Sex & Frequency & Percentage \\
\hline Man & 54 & 17.2 \\
Women & 248 & 82.8 \\
\hline Age & \\
\hline 18 or less & 144 & 47.7 \\
More than 18 & 158 & 52.3 \\
\hline Connected to the Internet & \\
\hline 3 or more hours a day & 182 & 63.0 \\
Less than 3 h & 120 & 37.0 \\
\hline Informed by internet & \\
\hline Daily & 253 & 83.8 \\
Less frequent & 49 & 16.2 \\
\hline Total & 302 & 100.0 \\
\hline Source: own elaboration.
\end{tabular}

The data matrix in the format of the SPSS statistical software package with all the detailed information is available for download at Mendeley Data in order to promote the transparency and replicability of the analyses [50].

\subsection{Instruments}

This study adapted and developed two instruments with different objectives: the level of digital citizenship to assess evolution in an initial data collection (pre-test) and another final one (post-test); and a workshop on the SDGs and related cyber interactions to validate and educate on sustainable development.

Specifically, the Choi, Glassman and Cristol Digital Citizenship Scale was used [51]. This approved scale $[52,53]$ is made up of 26 items grouped around five factors (see Table 2):

- Factor 1 consists of six items that measure the abilities of individuals to access the Internet, use digital technologies, find information and download applications. Since this factor is associated with basic digital literacy and skills for digital citizenship [54], it was called Technical Skills (TS).

- Factor 2 is made up of four items that measure the highest level of media literacy of individuals and technical skills focused on communication, interaction and posting. These highly developed skills or performance in the context of social networks is key to understanding transnational or global activism [55]. This factor was labelled as Networking Agency (NA).

- Factor 3 is made up of three items that measure individual awareness of social and political issues on local, national and global levels. The advent of the information society and the emergence of new information and communication technologies have accelerated the globalization process and, in this sense, have led certain authors to start talking about global digital citizenship [56]. As a result, this factor was called Local/Global Awareness (LGA).

- Factor 4 is made up of four items that measure a critical approach towards engagement in society and the perception of the Internet. This factor was called Critical Perspective (CP). 
- Factor 5 considers nine items that measure the political engagement of people on the Internet through unconventional political actions or, as stated above, cyber-activism [57]. As this factor is related to direct political engagement and involvement, it was called Political Activism on the Internet (PAI).

Table 2. Factors, labels, acronyms and items of the instrument: Digital Citizenship Scale.

\begin{tabular}{|c|c|}
\hline & Labels (Acronyms) and $\mathrm{n}^{\circ}$ Items \\
\hline \multirow[t]{5}{*}{1} & Technical Skills (TS) \\
\hline & I can use the Internet to find information I need. \\
\hline & I can use the Internet to find and download applications (apps) that are useful to me. \\
\hline & $\begin{array}{l}\text { 3. I am able to use digital technologies (e.g., mobile/smart phones, Tablet PCs, Laptops, PCs) to } \\
\text { achieve the goals I pursue. }\end{array}$ \\
\hline & $\begin{array}{l}\text { 4. I can access the Internet through digital technologies (e.g., mobile/smart phones, Tablet PCs, } \\
\text { Laptops, PCs) whenever I want. }\end{array}$ \\
\hline \multirow[t]{5}{*}{2} & Networking Agency (NA) \\
\hline & Where possible, I comment on other people's writings in news websites, blogs, or SNSs I visit. \\
\hline & 6. I enjoy communicating with others online. \\
\hline & 7. I enjoy collaborating with others online more than I do offline. \\
\hline & $\begin{array}{l}\text { 8. I post original messages, audio, pictures, or videos to express my } \\
\text { feelings/thoughts/ideas/opinions on the Internet. }\end{array}$ \\
\hline \multirow[t]{3}{*}{3} & Local/Global Awareness (LGA) \\
\hline & 9. I am more informed with regard to political or social issues through using the Internet. \\
\hline & 10. I am more aware of global issues through using the Internet. \\
\hline
\end{tabular}

4

11. I think online participation is an effective way to make a change to something I believe to be unfair or unjust.

12. I think I am given to rethink my beliefs regarding a particular issue/topic when I use the Internet.

13. I think online participation is an effective way to engage with political or social issues

14. I think online participation promotes offline engagement.

15. I think the Internet reflects the biases and dominance present in offline power structures.

16. I am more socially or politically engaged when I am online than offline.

17. I use the Internet in order to participate in social movement/change or protest.

$5 \quad$ Political Activism on the Internet (PAI)

18. I attend political meetings or public forums on local, town, or school affairs via online methods.

19. I work with others online to solve local, national, or global issues.

20. I organize petitions about social, cultural, political, or economic issues online.

21. I regularly post thoughts related to political or social issues online.

22. I sometimes contact government officials about an issue that is important to me via online methods.

23. I express my opinions online to challenge dominant perspectives or the status quo with regard to political or social issues.

24. I sign petitions about social, cultural, political, or economic issues online.

25. I work or volunteer for a political party or candidate via online methods.

26. I belong to online groups that are involved in political or social issues.

\begin{tabular}{lc}
\hline Total & Digital Citizenship (DC) 26 items \\
\hline & Source: own elaboration based on Choi, Glassman and Cristol [41].
\end{tabular}

The second instrument consists of an educational intervention in a workshop format aimed at training students in issues of digital engagement and cyber interactions in the field of the SDGs. Digital participation means any voluntary activity of citizens to influence public decisions channeled by telematic means [58]. One of the most widely used models on citizen participation is that of 
Arnstein [59], which establishes a scale that goes from less to more participation. Following this model, Borge [58] assigns different forms of electronic participation for each level of the ladder of citizen participation:

- Information: use of websites and email to disseminate information through documents, links, announcements, notifications, etc.

- Communication: two-way contacts via email or websites that allow for questions, suggestions, complaints, comments, etc.

- Consultation: use of electronic channels to carry out polls, surveys, referendums, etc.

- Deliberation: evaluation, reflection or debate on socio-political issues through forums, chats, debate spaces, etc.

- Participation in decisions and elections: electronic voting, binding referendums or surveys, petitioning, citizen consultations, etc.

All of these would be forms of conventional political participation, but there are other forms of unconventional participation that do not correspond to the norms and customs of a system and that are characteristic of social movements [60]. These forms of participation are channeled through activism and electronic protest that would consist of unconventional political actions on the Internet $[57,61]$. The level of participation is graduated following Marsh's scale of unconventional political action [62], which ranges from a level of low involvement, complexity and risk, such as signing an online petition, to actions bordering on the illegal, such as denial-of-service attacks (DoS). The workshop was developed using the 2030 Agenda as content, explaining the content of the sustainable development goals and their themes so that the students had a broad vision of social, political and environmental issues and demands on a global scale [63]. The students also had to consult various websites related to the SDGs. Links were provided to various websites of organizations that worked on aspects closely related to the SDGs (human rights, the environment, etc.). In the links provided, the students could choose between several to carry out various digital activism actions graduated according to a level from lowest to highest involvement and complexity, from clicktivism to hacktivism, among all those related to the SDGs (see Table 3).

Table 3. Levels of involvement, digital activities and links used in the workshop.

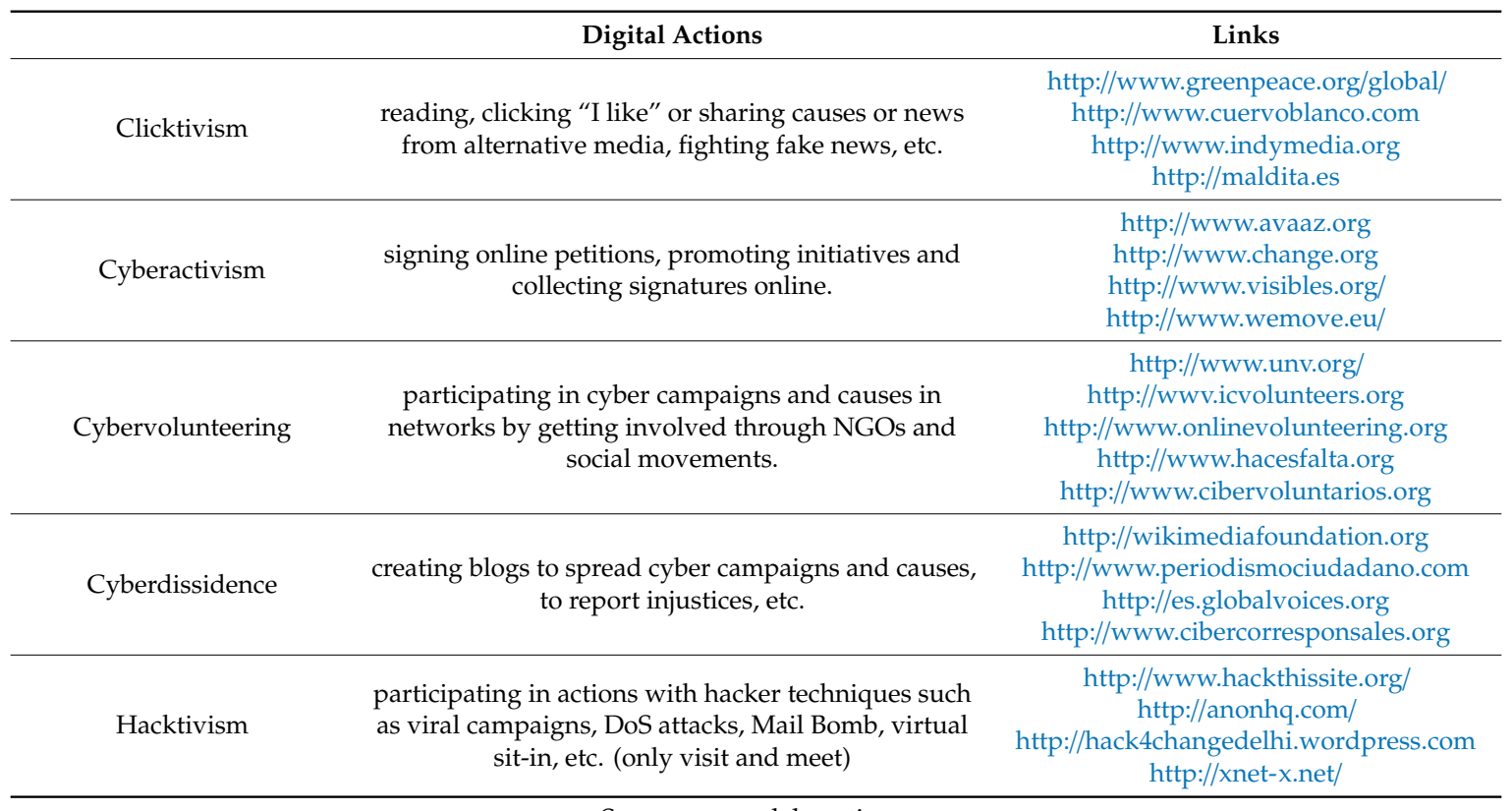

Source: own elaboration. 


\subsection{Procedure and Analysis}

The main aim of this study is to determine whether the education of SDGs through various related cybernetic interactions can significantly improve digital citizenship. To achieve these objectives, a procedure based on the pre-test/post-test methodological design was developed in three moments or stages from October 2019 to January 2020:

- Initially, an evaluation was carried out by administering the digital citizenship scale through the open source application LimeSurvey for online surveys (more information on the LimeSurvey website: the online survey tool-open source surveys URL: https://www.limesurvey.org). The questionnaire was sent out to the participants in the sample by email, following a brief explanation given in class on the objectives of this scale and how to complete it (October and November 2019).

- In the second stage, the educational intervention was carried out through the workshop described in the section above, aimed at training students in issues of digital engagement and the SDGs. For each level of digital engagement, the student had to carry out at least one action on any of the links provided (except for the level of hacktivism, for which they should have only known the pages). The workshop took place over two sessions of $1.5 \mathrm{~h}$ (November-December 2019).

- Finally, the Digital Citizenship Scale of Choi, Glassman and Cristol [51] was administered again online to students who had completed the previous two stages (December 2019-January 2020).

The analysis applied to the unique data matrix obtained from the pre-test and post-test measure of digital citizenship is shown in the following results section. First, some psychometric properties of the scale are described in each of its pre-test and post-test factors. Secondly, the mean differences in the different factors and in the total of the digital citizenship scale are presented in a graph form. Finally, the $t$-student statistic is assessed as to whether these differences are significant in the different factors and in certain characteristics of the sample.

\section{Results}

The main descriptive characteristics and psychometric properties of the digital citizenship scale used in each of its factors, both in the pre-test and post-test measure, are shown in Table 4 . In the analysis of the results, a linear transformation of the aggregate scores of the items corresponding to each factor has been carried out to obtain subscales of $0-10$. This gave a certain hierarchy or order from highest to lowest in the factors according to their arithmetic mean: Technical Skills (TS), Local/Global Awareness (LGA), Networking Agency (NA), Critical Perspective (CP) and Political Activism on the Internet (PAI). In other words, university students excel in technical skills on the Internet, but show very little online political participation or cyberactivism (NA, CP, PAI). The standard deviation provides a measure of the dispersion that in the case of the LGA factor is the most outstanding, implying a wide variability or diversity of this factor among the participants. Meanwhile, the psychometric properties of the Digital Citizenship (DC) scale as a whole achieves high reliability as shown by Cronbach's Alpha coefficient (0.89). All factors achieve reliability coefficients higher than 0.80 , except in the case of the "Networking Agency" factor, which hovers around 0.60.

The most significant results to verify the main objective of our research compare the pre-test and post-test measures of the DC scale and its different factors. Figure 1 shows that all the factors, except TS, increased, including the whole of the scale, DS, which rose from an average of 4.8 in the pre-test to more than 5.2 in the post-test. The positive differences between the highest pre-test and post-test arithmetic means are found, in order, in the following factors: PAI (diff $=0.7)$; CP (diff $=0.4)$; LGA $($ diff $=0.3)$; NA $($ diff $=0.2)$. 
Table 4. Description of the scales and psychometric properties by pre-test and post-test factors.

\begin{tabular}{cccc}
\hline Factors (Pre-Test and Post-Test) & Mean (0-10) & Std. Deviation & Cronbach's Alpha Coefficient \\
\hline TS pre-test & 9.0 & 1.64 & 0.87 \\
TS post-test & 8.9 & 2.12 & 0.94 \\
NA pre-test & 5.3 & 1.93 & 0.57 \\
NA post-test & 5.5 & 2.00 & 0.60 \\
LGA pre-test & 6.7 & 2.66 & 0.78 \\
LGA post-test & 7.0 & 2.63 & 0.82 \\
CP pre-test & 4.7 & 2.20 & 0.81 \\
CP post-test & 5.1 & 2.15 & 0.84 \\
PAI pre-test & 2.9 & 1.99 & 0.88 \\
PAI post-test & 3.6 & 2.17 & 0.89 \\
DC pre-test & 4.8 & 1.47 & 0.89 \\
DC post-test & 5.2 & 1.54 & 0.89 \\
\hline
\end{tabular}

Source: own elaboration.

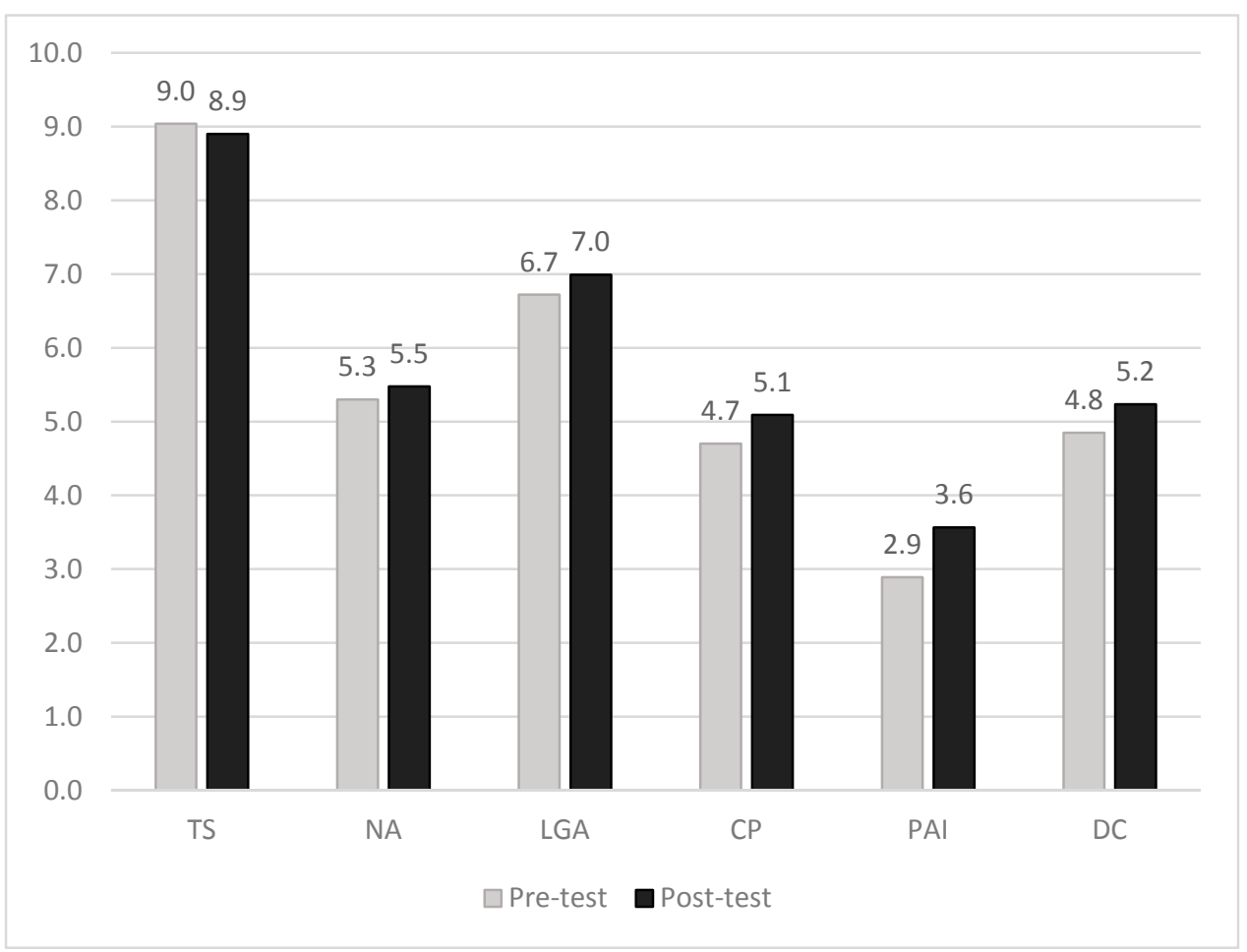

Figure 1. Comparison of means in the different factors (pre-test and post-test) of the Digital Citizenship Scale.

To check whether the differences of the arithmetic means between the pre-test and post-test measurements on the DC scale, as well as the five factors, are statistically significant, the $t$-student test was applied (see Table 5). On one hand, the increase in the DC scale as a whole, after the educational intervention of the workshop on the SDGs, is significant, as shown by $t(301)=-4.36, p<0.001$. On the other hand, two scale factors, PAI and CP, also obtain a statistically significant $t$-student: $t(301)=-5.30$, $p<0.001$ y $t(301)=-3.16, p=0.002$, respectively.

The significance of the difference of arithmetic means between the pre-test and the post-test of the DC scale has also been verified according to certain sociodemographic variables (sex and age) and characteristics of the sample with respect to their relationship with the Internet (time connected to the Internet per day and frequency of Internet use for information). These variables have been dichotomized to guarantee the maximum possible number of cases in each category (see Table 6). This proves that the increase in DC levels, after educational intervention, was significant among female 
students, while it was not significant among male students. Likewise, the participants who receive information each day significantly increased their results on the Digital Citizenship scale, but this was not the case among those who did so less frequently. On the contrary, whether the students were younger or not, or were connected for more than three hours or less, they showed significant increases in DC levels between the pre-test and post-test measurements ( $t$-student test).

Table 5. Calculation of $t$-student for each of the factors (pre-test and post-test).

\begin{tabular}{cccc}
\hline Factors (Paired Pre-Test and Post-Test) & $\boldsymbol{t}$ & $\mathbf{d f}$ & Sig. (2-Tailed) \\
\hline HS (pre-test and post-test) & 1.06 & 301 & 0.288 \\
NA (pre-post) & -1.52 & 301 & 0.129 \\
LGA (pre-post) & -1.62 & 301 & 0.106 \\
CP (pre-post) & -3.16 & 301 & 0.002 \\
PAI (pre-post) & -5.30 & 301 & 0.000 \\
DC (pre-post) & -4.36 & 301 & 0.000 \\
\hline
\end{tabular}

Source: own elaboration.

Table 6. Significant differences (pre-test and post-test) in the Digital Citizenship scale for some characteristics of the sample.

\begin{tabular}{|c|c|c|c|c|c|}
\hline & \multicolumn{2}{|c|}{ Pre-Test } & \multicolumn{2}{|c|}{ Post-Test } & \multirow[b]{2}{*}{$t$-Student } \\
\hline & Mean & S.D. & Mean & S.D. & \\
\hline \multicolumn{6}{|l|}{ Sex } \\
\hline Male & 5.3 & 1.41 & 5.6 & 1.51 & $t(53)=-1.57, p=0.122$ \\
\hline Female & 4.8 & 1.47 & 5.2 & 1.54 & $t(247)=-4.06, p<0.001$ \\
\hline F-Snedecor & \multicolumn{2}{|c|}{$F(1)=5.45 \cdot p=0.020$} & \multicolumn{2}{|c|}{$F(1)=3.28 . p=0.071$} & \\
\hline \multicolumn{6}{|l|}{ Age } \\
\hline $17-18$ & 5.1 & 1.46 & 5.5 & 1.56 & $t(143)=-2.86, p=0.005$ \\
\hline Over 18 & 4.6 & 1.46 & 5.0 & 1.49 & $t(157)=-3.29, p=0.001$ \\
\hline F-Snedecor & \multicolumn{2}{|c|}{$F(1)=7.89 . p=0.005$} & \multicolumn{2}{|c|}{$F(1)=6.58 . p=0.011$} & \\
\hline \multicolumn{6}{|l|}{ Time connected } \\
\hline 3 or more hours a day & 5.0 & 1.51 & 5.3 & 1.51 & $t(181)=-2.52, p=0.012$ \\
\hline Less than $3 \mathrm{~h}$ & 4.6 & 1.37 & 5.1 & 1.60 & $t(106)=-3.31, p=0.001$ \\
\hline F-Snedecor & \multicolumn{2}{|c|}{$F(1)=6.05 . p=0.014$} & \multicolumn{2}{|c|}{$F(1)=1.94 . p=0.165$} & \\
\hline \multicolumn{6}{|l|}{ Internet use for information } \\
\hline Daily & 4.9 & 1.44 & 5.3 & 1.53 & $t(247)=-4.06, p<0.001$ \\
\hline Less frequent & 4.5 & 1.59 & 4.7 & 1.44 & $t(48)=-0.97, p=0.335$ \\
\hline F-Snedecor & \multicolumn{2}{|c|}{$F(1)=3.14 . p=0.078$} & \multicolumn{2}{|c|}{$F(1)=7.54 . p=0.006$} & \\
\hline
\end{tabular}

Source: own elaboration.

However, the differences in the initial pre-test evaluations between the younger and older students, between the most and least connected to the Internet, between men and women, the workshop on SDGs and cyber interactions triggered differences in the post-test, which in some cases saw statistical significance disappear and in others saw it appear. In this sense, it should be noted that the educational intervention eliminated the significant differences that existed by sex and by connection time in the pre-test. On the contrary, the differences between those who did or did not take information each day from the Internet went from not being significant in the pre-test to being significant in the post-test (F-Snedecor tests).

\section{Discussions}

In the first objective of this study, the aim was to find out the characteristics of digital citizenship of Education undergraduates. The results confirm what was to be expected, i.e., a low level of development of active, critical and political engagement on the Internet. The students state that they 
have a good level of technical skills and, to a much lower degree, say they take in information about what is happening in their local and global environment. However, this highly technical skill does not involve a digital, socio-political engagement. Most likely they are not aware of the potential of internet as a tool for political engagement. The students can also state their political views by engaging in social causes and realities such as inequalities, environmental problems, political corruption, etc. As a logical and expected consequence, the students hardly show any activity committed to the protection of human rights, environmental commitment and social justice through the various options of more committed, and less conventional, political action that can be found online and which would be in line with a personal involvement for transformative action $[13,64]$. Other studies $[46,47]$ show similar results regarding good technical skills over low use of the Internet as a digital activism tool.

The second objective was to find out how these aspects of local/global awareness, networking agency, critical perspective and political activism on the Internet are modified, by means of an education in sustainability and awareness workshop focused on the Sustainable Development Goals. The results are revealing as they show an important improvement in the digital citizenship skills of students. Above all, Critical Perspective and Political Activism on the Internet are proven to play a key role. It is surprising to see the variability found around the use of the Internet to take in information about reality (Local/Global Awareness). This would show a wide range of levels within this factor and would be an aspect to consider in education in sustainability, given the importance of knowing the environmental, economic, political and sociocultural reality [12]. The Social Network Activity factor improves, although not significantly, which is probably due to the fact that it focuses on advanced digital skills, something that is difficult to improve in a three-hour workshop. The Critical Perspective factor improves significantly, and the students positively reconsider the importance and potential of the network to engage in socio-political issues, commit to real life, protest socially and fight for what they consider fair, as well as to rethink their own ideas. The aspect that gives the most significant improvement is the Political Activism on the Internet factor, i.e., there is an increase in the defense of their own opinion in unfair situations, collaboration with others to solve local/national/global problems, the collection/signing of online petitions on social or political issues, the exercise of online volunteering activities for organizations on issues related to the SDG theme, etc. The intervention on content related to the SDGs leads to an overall improvement in critical, active and empowering digital engagement to fight for social justice and human development (Digital Citizenship). By gender, there is an especially high and significant improvement in the case of women, with the difference that existed by sex before carrying out the SDG education disappearing, i.e., women seem to show a greater predisposition to modify their initial positions on sustainability, with similar results being found by Cifuentes-Faura, Faura-Martínez and Lafuente-Lechuga [65]. Despite this, it is a question to consider with caution given the overrepresentation of women: $82.8 \%$ compared to $17.2 \%$. In short, with these results, the compensating effect of unconventional civic education in young people with little exposure to it can be observed [66]. Like in this study, other authors [67-70], reveal that critical awareness and digital political engagement are increased by the use of well thought out activities to promote civic action and online engagement. This study would be a sample of how to educate citizens on and for the achievement of the SDGs from critical pedagogy approaches that use unconventional forms of political action to exercise citizenship [71].

Some of the weaknesses of this study were the small sample size and the limited time dedicated to the intervention. However, the workshop format, together with the cross-cutting nature of the SDGs, makes it easily transferable to any type of university degree, not just to future teachers. Studies on sustainability focused on potential gender differences to ease developing strategies to achieve SDGs would also be of interest. Meanwhile, it would be desirable to have longitudinal studies that include long-term education for the achievement of the SDGs from the digital sphere, as in one academic year or more, to study to what extent civic commitment is bolstered and consolidated over time. Likewise, it would be important to see what possible differences may exist between the students depending on their degree, given that it is desirable to ensure that the values of sustainability are included in the 
different university degrees. This is because, ideally, they are intended to transfer these aspects in the future to the various areas of managing society and bolstering civic engagement. In addition to exploring this line of research on syllabus-based sustainability or the mainstreaming of the principles of sustainability in all areas of knowledge, it is promising to delve into future research, given that the synergy of digital resources or actions favor not only an increased digital citizenship, but also the achievement of the SDGs.

Author Contributions: All authors contributed equally to this work. All authors have read and agreed to the published version of the manuscript.

Funding: This research was funded by CentrA Foundation grant number PRY109/19.

Conflicts of Interest: The authors declare no conflict of interest.

\section{References}

1. Resolution Adopted by the General Assembly 70/1 “Transforming Our World: The 2030 Agenda for Sustainable Development" A/RES/70/1 (25 September 2015). Available online: https://undocs.org/en/A/RES/ 70/1 (accessed on 20 May 2020).

2. Murga-Menoyo, M.A. Citizenship Education in the Framework of 2030 Agenda and Environmental Justice. Rev. Int. Educ. Justicia Soc. 2018, 7, 37-56. [CrossRef]

3. UNESCO. Education for Sustainable Development Goals: Learning Objectives; UNESCO: París, France, 2017. Available online: https://unesdoc.unesco.org/ark:/48223/pf0000247444 (accessed on 20 May 2020).

4. CADEP-CRUE. Directrices Para la Introducción de la Sostenibilidad en el Curriculo. Documento Aprobado por el Comité Ejecutivo del Grupo de Trabajo de Calidad Ambiental y Desarrollo Sostenible de la CRUE, Celebrado en Valladolid el 18 de abril de 2005, Revisado y Actualizado en Marzo de 2011. Available online: http://www.cr ue.org/Documentos\%20compartidos/Declaraciones/Directrices_Sosteniblidad_Crue2012.pdf (accessed on 20 May 2020).

5. Murga-Menoyo, M.A. Universidades en transición. Hacia una transformación institucional orientada al logro de la sostenibilidad. Rev. Iberoam. Educ. 2017, 73, 61-84. [CrossRef]

6. Olsson, D.; Gericke, N.; Sass, W.; Pauw, J.B. Self-perceived action competence for sustainability: The theoretical grounding and empirical validation of a novel research instrument. Environ. Educ. Res. 2020, 26, 742-760. [CrossRef]

7. Westheimer, J. Can Education Transform the World? Kappa Delta Pi Record 2020, 56, 6-12. [CrossRef]

8. Quan, T.; Bracho, C.A.; Wilkerson, M.; Clark, M. Empowerment and transformation: Integrating teacher identity, activism, and criticality across three teacher education programs. Rev. Educ. Pedagog. Cult. Stud. 2019, 41, 218-251. [CrossRef]

9. García-Esteban, F.E.; Murga-Menoyo, M.A. Childhood Education Teachers towards Sustainable Development. Training needs. Enseñ. Teach. 2015, 33, 121-142. [CrossRef]

10. Sánchez-Carracedo, F.; Ruiz-Morales, J.; Valderrama-Hernández, R.; Muñoz-Rodríguez, J.M.; Gomera, A. Analysis of the presence of sustainability in Higher Education Degrees of the Spanish university system. Stud. High. Educ. 2019, 1-18. [CrossRef]

11. Varela-Losada, M.; Arias-Correa, A.; Pérez-Rodríguez, U.; Vega-Marcote, P. How Can Teachers Be Encouraged to Commit to Sustainability? Evaluation of a Teacher-Training Experience in Spain. Sustainability 2019, 11, 4309. [CrossRef]

12. Vila, E.S.; Caride, J.A.; Buxarrais, M.R. Educación, sostenibilidad y ética: Desafíos ante los objetivos de desarrollo sostenible (ODS). In Proceedings of the XXXVII Seminario de Teoría de la Educación: Educación en la Sociedad del Conocimiento y el Desarrollo Sostenible, SITE, Tenerife, Spain, 11-14 November 2018; pp. 1-40. Available online: https://riull.ull.es/xmlui/handle/915/11657 (accessed on 1 May 2020).

13. Plaza-de la Hoz, J. Cómo mejorar el papel de las TIC para promover una educación empoderadora en el desarrollo sostenible. Aloma 2018, 36, 43-55.

14. Gonzalo, V.; Sobrino, M.R.; Benítez, L.; Coronado, A. Revisión sistemática sobre competencias en desarrollo sostenible en educación superior. Rev. Iberoam. Educ. 2017, 73, 85-108. [CrossRef] 
15. Lozano, R.; Merrill, M.Y.; Sammalisto, K.; Ceulemans, K.; Lozano, F.J. Connecting Competences and Pedagogical Approaches for Sustainable Development in Higher Education: A Literature Review and Framework Proposal. Sustainability 2017, 9, 1889. [CrossRef]

16. Wals, A.E.J. Sustainability in higher education in the context of the UN DESD: A review of learning and institutionalization processes. J. Clean. Prod. 2014, 62, 8-15. [CrossRef]

17. Lozano, R.; Barreiro-Gen, M.; Lozano, F.; Sammalisto, K. Teaching Sustainability in European Higher Education Institutions: Assessing the Connections between Competences and Pedagogical Approaches. Sustainability 2019, 11, 1602. [CrossRef]

18. Albareda-Tiana, S.; Vidal-Raméntola, S.; Fernández-Morilla, M. Implementing the sustainable development goals at University level. Int. J. Sustain. High. Educ. 2018, 19, 473-497. [CrossRef]

19. Valderrama-Hernández, R.; Alcántara, L.; Sánchez-Carracedo, F.; Caballero, D.; Serrate, S.; Gil-Doménech, D.; Vidal-Raméntol, S.; Miñano, R. Does the Spanish university system teach sustainability? Perception of the students of four universities. Educación XX1 2020, 23, 221-245. [CrossRef]

20. Solís-Espallargas, C.; Valderrama-Hernández, R. La educación para la sostenibilidad en la formación de profesorado. ¿Qué estamos haciendo? Foro de Educación 2015, 13, 165-192. [CrossRef]

21. Valderrama-Hernández, R.; Sánchez-Carracedo, F.; Alcántara, L.; Limón-Domínguez, D. Methodology to Analyze the Effectiveness of ESD in a Higher Degree in Education. A Case Study. Sustainability 2019, 12, 222. [CrossRef]

22. Solís-Espallargas, C. The perception of the sustainability in students of the Master in education about sustainable development goals. Revista Espacios 2019, 40, 11-22.

23. United Nations. The Sustainable Development Goals Report 2020. Available online: https://unstats.un.org/s dgs/report/2020/The-Sustainable-Development-Goals-Report-2020.pdf (accessed on 18 May 2020).

24. Yildiz, M.N.; Keengwe, J. Handbook of Research on Media Literacy in the Digital Age; IGI Global: Hershey, PA, USA, 2016. [CrossRef]

25. Khosrow-Pour, M. Encyclopedia of Information Science and Technology, 4th ed.; ICI Global: Hershey, PA, USA, 2018. [CrossRef]

26. Ribble, M. Digital Citizenship for Educational Change. Kappa Delta Pi Record 2012, 48, 148-151. [CrossRef]

27. Curran, M.B.F.X.; Ribble, M. P-20 Model of Digital Citizenship. New Dir. Stud. Leadersh. 2017, 153, 35-46. [CrossRef]

28. Gleason, B.; von Gillern, S. Digital Citizenship with Social Media: Participatory Practices of Teaching and Learning in Secondary Education. J. Educ. Technol. Soc. 2018, 21, 200-212. Available online: https://lib.dr.iastate.edu/edu_pubs/100 (accessed on 15 July 2020).

29. Emejulu, A.; McGregor, C. Towards a radical digital citizenship in digital education. Crit. Stud. Educ. 2016, 60, 131-147. [CrossRef]

30. DeLeon, A. The time for action is now! anarchist theory, critical pedagogy, and radical possibilities. J. Crit. Educ. Policy Stud. 2006, 4, 72-94. Available online: http://www.jceps.com/?pageID=article\&articleID=67 (accessed on 20 August 2020).

31. Kahne, J.; Hodgin, E.; Eidman-Aadahl, E. Redesigning civic education for the digital age: Participatory politics and the pursuit of democratic engagement. Theory Res. Soc. Educ. 2016, 44, 1-35. [CrossRef]

32. Recommendation CM/Rec(2019)10 of the Committee of Ministers to Member States on Developing and Promoting Digital Citizenship Education (21 November 2019). Available online: https://search.coe.int/cm/Pa ges/result_details.aspx?ObjectID=090000168098de08 (accessed on 18 May 2020).

33. Schroeder, S.; Currin, E.; Washington, E.; Curcio, R.; Lundgren, L. "Like, Share, Comment," and Learn: Transformative Learning in Online Anti-Trump Resistance Communities. Adult Educ. Q. 2020, 70, 119-139. [CrossRef]

34. Ramasubramanian, S.; Darzabi, R.C. Civic Engagement, Social Justice, and Media Literacy. In Media Literacy in a Disruptive Media Environment, 1st ed.; Christ, W., Abreu, B., Eds.; Routledge: New York, NY, USA, 2020; pp. 2-20. [CrossRef]

35. Blevins, B.; LeCompte, K.; Wells, S. Innovations in Civic Education: Developing Civic Agency Through Action Civics. Theory Res. Soc. Educ. 2016, 44, 344-384. [CrossRef]

36. Loader, B.D.; Vromen, A.; Xenos, M.A. The networked young citizen: Social media, political participation and civic engagement. Inf. Commun. Soc. 2014, 17, 143-150. [CrossRef] 
37. Amin, R. The empire strikes back: Social media uprisings and the future of cyber activism. Kennedy Sch. Rev. 2009, 10, 64-67.

38. Amgott, N. Critical Literacy in \#DigitalActivism: Collaborative Choice and Action. Int. J. Inf. Learn. Technol. 2018, 35, 329-341. [CrossRef]

39. Morozov, E.; The Brave New World of Slacktivism. Foreign Policy 2009. Available online: https://foreignpol icy.com/2009/05/19/the-brave-new-world-of-slacktivism/ (accessed on 20 May 2020).

40. Calenda, D.; Meijer, A. Young people, the Internet and political participation: Findings of a web survey in Italy, Spain and the Netherlands. Inf. Commun. Soc. 2009, 12, 879-898. [CrossRef]

41. Boulianne, S. Social media use and participation: A metaanalysis of current research. Inf. Commun. Soc. 2015, 18, 524-538. [CrossRef]

42. Carragee, K.M. Communication, Activism and the News Media: An Agenda for Future Research. Commun. Soc. 2019, 32, 361-378. [CrossRef]

43. García-Galera, M.C.; del Hoyo-Hurtado, M.; Fernández-Muñoz, C. Engaged Youth in the Internet. The Role of Social Networks in Social Active Participation. Comunicar 2014, 22, 35-43. [CrossRef]

44. Halupka, M. The legitimisation of clicktivism. Aust. J. Polit. Sci. 2017, 53, 1-13. [CrossRef]

45. Piat, C. Slacktivism: Not Simply a Means to an End, but a Legitimate Form of Civic Participation. Can. J. Family Youth 2019, 11, 162-179. [CrossRef]

46. Lozano-Díaz, A.; Fernández-Prados, J.S. Ciudadanía digital y su medida: Propiedades psicométricas de una escala y retos para la educación superior. EKS Educ. Knowl. Soc. 2018, 19, 83-102. [CrossRef]

47. Lozano-Díaz, A.; Fernández-Prados, J.S. Hacia una educación para la ciudadanía digital crítica y activa en la universidad. RELATEC Rev. Latinoam. Tecnol. Educ. 2019, 18, 175-189. [CrossRef]

48. Yoon, S.; Kim, S.; Jung, Y. Needs Analysis of Digital Citizenship Education for University Students in South Korea: Using Importance-Performance Analysis. Educ. Technol. Int. 2019, 20, 1-24. [CrossRef]

49. Ahlquist, J. Infusing Digital Citizenship into Higher Education. 2014. Available online: https://www.josieahl quist.com/2014/01/27/infusing-digital-citizenship-into-higher-education/ (accessed on 27 May 2020).

50. Fernández-Prados, J.S.; Lozano-Díaz, A. Estudio de la Educación para los ODS y Ciudadanía Digital, Mendeley Data, v1. 2020. Available online: http://dx.doi.org/10.17632/3ytmd9jjyh.1 (accessed on 15 July 2020).

51. Choi, M.; Glassman, M.; Cristol, D. What it means to be a citizen in the internet age: Development of a reliable and valid digital citizenship scale. Comput. Educ. 2017, 107, 100-112. [CrossRef]

52. Choi, M. Development of a Scale to Measure Digital Citizenship among Young Adults for Democratic Citizenship Education; Ohio State University: Columbus, OH, USA, 2015; Available online: https://etd.ohiolink.ed (accessed on 20 May 2020).

53. Choi, M. A concept analisys of Digital Citizenship for Democratic Citizenship Education in the Internet Age. Theory Res. Soc. Educ. 2016, 44, 565-607. [CrossRef]

54. Dias-Fonseca, T.; Potter, J. La educación mediática como estrategia de participación cívica online en las escuelas portuguesas. Comunicar 2016, 24, 9-18. [CrossRef]

55. Martínez Martínez, M.J. Prácticas Mediáticas y Movimientos Sociales: El Activismo Trasnacional de Marea Granate. Index Comun. 2017, 7, 31-50.

56. Crockett, L.W.; Churches, A. Growing Global Digital Citizens. Better Practices That Build Better Learners; Solution Tree Press: Bloomington, IN, USA, 2018.

57. Fernández-Prados, J.S. Cyberactivism: Conceptualization, Hypothesis and measurement. ARBOR Cienc. Pensam. Cult. 2012, 188, 631-639. [CrossRef]

58. Borge, R. La participación electrónica: Estado de la cuestión y aproximación a su clasificación. Rev. Int. Derecho Política 2005, 1, 1-15.

59. Arnstein, S. A ladder of Citizen Participation. J. Am. Inst. Plan. 2007, 35, 216-224. [CrossRef]

60. Rucht, D. Estrategias y formas de acción. In Los Nuevos Movimientos Sociales, 2nd ed.; Dalton, R.J., Kuechler, M., Eds.; Edicions Alfons el Magnánim: Valencia, Spain, 1992; pp. 219-246.

61. Fernández-Prados, J.S.; Rojas-Tejada, A.J. Analysis of the Unconventional Political Action Scale: Results in Spain. Field Methods 2003, 15, 131-142. [CrossRef]

62. Marsh, A. Protests and Political Consciousness, 2nd ed.; Sage: Beverly Hills, CA, USA, 1977.

63. Lozano-Díaz, A.; Figueredo-Canosa, V.; Fernández-Prados, J.S. Sustainable Development Goals and Digital Citizenship. In Proceedings of the 8th International Conference on Information and Education Technology, ICIET, Okayama, Japan, 28-30 March 2020. [CrossRef] 
64. Krings, A.; Austic, E.A.; Gutiérrez, L.; Dirksen, K.E. The Comparative Impacts of Social Justice Educational Methods on Political Participation, Civic Engagement, and Multicultural Activism. Equity Excell. Educ. 2015, 48, 403-417. [CrossRef]

65. Cifuentes-Faura, J.; Faura-Martínez, U.; Lafuente-Lechuga, M. Assessment of Sustainable Development in Secondary School Economics Students According to Gender. Sustainability 2020, 12, 5353. [CrossRef]

66. Campbell, D.E. What Social Scientists Have Learned About Civic Education: A Review of the Literature. Peabody J. Educ. 2019, 94, 32-47. [CrossRef]

67. Bowyer, B.; Kahne, J. The digital dimensions of civic education: Assessing the effects of learning opportunities. J. Appl. Dev. Psychol. 2020, 69, 101162. [CrossRef]

68. Kahne, J.; Bowyer, B. Can media literacy education increase digital engagement in politics? Learn. Media Technol. 2019, 44, 211-224. [CrossRef]

69. Kwon, L.; de los Ríos, C.V. "See, click, fix": Civic interrogation and digital tools in a ninth-grade ethnic studies course. Equity Excell. Educ. 2019, 52, 154-166. [CrossRef]

70. Tabuenca, B.; Kalz, M.; Löhr, A. Massive Open Online Education for Environmental Activism: The Worldwide Problem of Marine Litter. Sustainability 2019, 11, 2860. [CrossRef]

71. Nelsen, M. Cultivating Youth Engagement: Race \& the Behavioral Effects of Critical Pedagogy. Polit. Behav. 2019, 1-34. [CrossRef]

(C) 2020 by the authors. Licensee MDPI, Basel, Switzerland. This article is an open access article distributed under the terms and conditions of the Creative Commons Attribution (CC BY) license (http://creativecommons.org/licenses/by/4.0/). 